\title{
MISCELLANEA
}

\section{A House-Surgeon's Observations on Bronchitis in North Staffordshire Pottery Workers in 1864}

\author{
A. MEIKLEJOHN \\ From the Department of Industrial Health, University of
Glasgow
}

(RECEIVED FOR PUBLICATION FEBRUARY 18, 1957)

Charles Parsons was born on February 6, 1833, and died in his ninetieth year on March 24, 1922. In 1855 he obtained the diplomas of M.R.C.S. and L.S.A. After holding the offices of house physician and assistant house surgeon at King's College Hospital, London, in the summer of 1859 he was appointed house surgeon to the North Staffordshire Infirmary, which post he held until November, 1862. His patients were for the most part potters, colliers, and iron-workers. Respiratory diseases, acute and chronic, were prevalent among these workers. Dr. Parsons became very interested in these diseases of potters, particularly as they seemed to be caused by their occupations. He made careful observations, which he embraced in a thesis entitled On a Form of Bronchitis (simulating phthisis) which is Peculiar to Certain Branches of the Potting Trade. For this the University of Edinburgh in 1864, awarded him the degree of M.D. with Gold Medal.

From the Dover poll books it appears that he began practice in that town about 1868 and he continued there until he retired to Tunbridge Wells in 1909 . For a period of 30 years he was a consulting medical officer to the Royal Victoria Hospital at Dover. In addition to his high standing as a physician in the area, he was regarded as one of the worthies of the town. He was a fine musician and for many years he played the viola in the concerts organized by the Choral Union of which he was president from 1907 to 1909 . Education was another of his interests and he played a prominent part in the founding of Dover College. Medical politics, however, were perhaps his main activity. For many years he was secretary and treasurer and later president of the South Eastern Division (Kent, Sussex, and Surrey) of the British Medical Association of which he became a member of Council and held the office of treasurer. In his family life he knew sadness and glory. He had seven sons and four daughters; two of his sons were killed in the South African War, one being awarded the Victoria Cross: three other sons were killed in the 1914-18 war.

I have already mentioned that from 1859 to 1862 nearly 100 years ago-Dr. Parsons served as a house

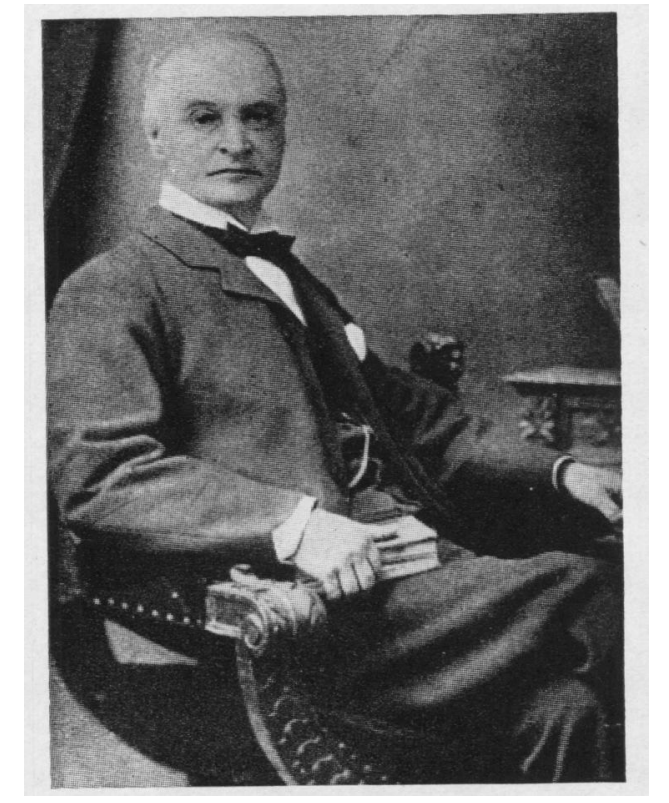

Photograph of Charles Parsons, M.D., taken for the " comingof-age " souvenir published by the Dover Choral Union during the period of his Presidency from 1907 to 1909.

surgeon at the North Staffordshire Infirmary. It was during this period that he collected the material for his M.D. thesis. In the introduction he claims that the thesis (1864) is the first published account of this " form of bronchitis" in potters. The thesis is a short essay of about 5,000 words. It consists of an account of his clinical and pathological observations, illustrated by details, including post-mortem findings, of three cases which had come under his care. He emphasizes that the local population were much opposed to post-mortem examinations. Indeed he asserts that "frequently it happens that patients in a dying state insist on being removed to their homes to die, merely to avoid the possibility of a post-mortem examination without their sanction, should death occur in the Infirmary ". This accords with the later experience of Dr. J. T. Arlidge, Consulting Physician to the North Staffordshire Infirmary, who delivered the Milroy Lectures on "Occupations and Trades in Relation to Public Health " at the Royal College of Physicians in 1889 (Arlidge, 1889). In connexion with the three necropsies recorded by Parsons it is of interest that as a preliminary to investigation " the lungs were injected". 
At present in Great Britain many workers are actively pursuing investigations into bronchitis and emphysema in the general population and among workmen exposed to harmful dusts. These enquiries embrace the epidemiology, clinical manifestations, bacteriology, pathology, and measurement of pulmonary function. The following excerpts from Dr. Parsons' thesis are of interest, revealing, as they do, the thoughts of a young physician on these subjects nearly a century ago.

\section{Identification of the Disease}

"The signs and symptoms proper to one disease have sometimes manifested themselves in another differing entirely from it in nature and essence, so that two distinct diseases have been confounded merely from some similarity in their phases. It is only when their morbid anatomy has been carefully investigated and patiently studied that we are able rightly to interpret their pathology, and to reconcile apparently opposite diseases with nearly identical signs and symptoms."

\section{Excavation of Fibrotic Tissue}

" Bronchial glands at root of lung filled with black matter. One which has softened in the centre is of the size of a walnut, and contains a matter not gritty, but of appearance, feel, and consistency of thick black grease."

\section{Action of Dust and Fibrosis}

“ Independently of the thickening and hypertrophy of the walls of the bronchial tubes resulting from inflammation, the presence of fine dust acting as a foreign body creates irritation of the mucous surface, followed by exudation from the bronchial membrane in which probably the dust is embedded. In this way the tubes become narrowed directly, and respiration is impeded; and indirectly by the pressure of infiltrated exudation matter which sometimes extends beyond the walls of the tubes, and encroaches on the adjacent lung substance. This diminution of calibre and constriction may gradually lead to obliteration of the finer bronchi, and to collapse of the air vesicles in which they terminate. Nay, more, it is not impossible that particles of fine dust may find their way into the minute air-cells themselves, and induce changes in them similar to those which take place in the air-tubes.

But this induration-matter may impede the function of the lung-substance in another way, by obliterating the vessels distributed to it and cutting off its supply of blood, so that atrophy of the tissues follows; and by obstructing the capillary circulation local congestion is favoured, and the blood but imperfectly oxygenated. Hence arises distressing dyspnoea and a dusky hue of the face.

Under circumstances such as these it is, I apprehend, that the emphysema recorded is apt to occur. Many are the theories that have been offered in explanation of its mechanism, and none of them is entirely satisfactory. Most of them have some truth in them, but not the whole truth. Neither of them is applicable in every instance."

\section{The Development of Emphysema}

" I venture, therefore, to offer the following explanation, as that which coincides most readily with the anatomical characters of the disease I am describing:-

It is not improbable that the act of coughing of itself is sufficient to cause some dilatation of even healthy air-vesicles if continued for a number of years; for the glottis being closed, and the walls of the chest, the diaphragm, etc., thrown into violent contraction, the pressure that is exercised upon the air-cells during the act must be enormous. But when to this is added the obliteration of some vesicles, the diminished expansion of others, and obstruction of the finer bronchi through the infiltration of exudation-matter, the strain that is thrown upon the patulous tubes and cells is necessarily so much the greater, whilst their elastic resistance remains the same, and dilatation is the consequence.

If, then; such change can take place in air-cells whose walls are healthy, how much more likely is the distension to occur in vesicles whose parietes are degenerated ? I have already shown in what manner the small vessels surrounding the air-cells are obliterated; and the nutritive supply being cut off, atrophy of the walls must follow as a natural sequence. Independently of this, however, the mere act of distension alone by compressing the capillaries between the vesicles cannot but interfere with the nutrition of the texture, and initiate atrophic changes favourable to further distension. This emphysematous condition is usually observed on the surface of the lung where it is most deficient of support.

Again, commensurate with this deficiency of nutrition in the air vesicles is the impairment of their elasticity and tonicity. They become as it were paralysed, and offer little or no resistance to the ingress of air in excess, whilst at the same time they contribute but feebly to its expulsion; a large portion of it apparently remaining stagnant, and the remainder being slowly expired."

\section{REFERENCES}

Arlidge, J. T. (1889) Brit med, J. 1, 580,642, 702, 766 . Parsons, C. (1864). Thesis: Maclachlan and Stewart, Edinburgh. 